\title{
PEMANFAATAN NERACA PENATAGUNAAN TANAH DALAM MENDUKUNG PENYUSUNAN SISTEM INFORMASI KETAHANAN PANGAN POKOK WILAYAH (Studi Di Kabupaten Sleman, Daerah Istimewa Yogyakarta)
}

\author{
Samudra Ivan Supratikno \\ Kantor Direktorat Jendral Penataan Agraria \\ Kementerian Agraria dan Tata Ruang/Badan Pertanahan Nasional \\ samudra@mail.ugm.ac.id \\ Armaidy Armawi \\ Fakultas Filsafat Universitas Gadjah Mada \\ Djaka Marwasta \\ Fakultas Geografi Universitas Gadjah Mada
}

\begin{abstract}
The development of food security towards food self-sufficiency was geared to sustained the strength of the domestic economy. Unfortunately, the development of residential necessity was not in line with the development of agricultural allocation that should be prepared as the availability of agricultural land to met the primary needs of population.

The study aimed to analyzed the balance of agricultural land use and its impact on main food resilience. The study also aimed to determined the level of food insecurity in supporting food resilience analysis in the area of Sleman. The study was located in Sleman, Yogyakarta Province. The method used descriptive analytical quantitative and overlaying method to performed spatial analysis. The findings were textual and spatial data output to saw the food resilience condition in the study areas.

In Sleman, food resilience condition with highly resistant level was in the district of Cangkringan, whereas in the districts of Sleman and Moyudan had experienced in a very vulnerable level. Based on the calculated statistical indicators; the level of access to food, land use suitability, and the availability of land used as a valid and reliability aspects of food resilience assessment. The data used in the analysis of food resilience were agriculture and nonagriculture areas to determined the index value of agricultural land for determining insecurity food. According to analysis using determinant of food resilience index, it showed that the condition of 15 Districts in Sleman were in the category food resilience areas and 2 sub-districts namely Sleman and Depok were classified into the category of potentially food-insecure areas.
\end{abstract}

Keyword: Balance, Land use, Agriculture, Main Food Resilience of Region

\begin{abstract}
ABSTRAK
Pembangunan ketahanan pangan menuju kemandirian pangan diarahkan untuk menopang kekuatan ekonomi domestik. Peningkatan kebutuhan permukiman sayangnya tidak sejalan dengan perkembangan terhadap alokasi
\end{abstract}


Samudra Ivan Supratikno, Armaidy Armawi, dan Djaka Marwasta -- Pemanfaatan Neraca Penatagunaan Tanah Dalam Mendukung Penyusunan Sistem Informasi Ketahanan Pangan Pokok Wilayah

(Studi Di Kabupaten Sleman, Daerah Istimewa Yogyakarta)

kebutuhan lahan pertanian yang seharusnya juga disiapkan sebagai ketersediaan tanah pertanian untuk memenuhi kebutuhan primer penduduknya.

Tujuan penelitian ini menganalisis perimbangan (neraca) penggunaan tanah pertanian dan dampaknya terhadap ketahanan pangan pokok dan mengetahui tingkat kerawanan pangan untuk mendukung analisis ketahanan pangan pokok wilayah di wilayah Kabupaten Sleman. Lokasi penelitian di Kabupaten Sleman, Propinsi Daerah Istimewa Yogyakarta. Metode penelitian menggunakan analisis kuantiatif-deskriptif dan metode tumpang susun untuk melakukan analisis keruangannya. Penelitian ini menghasilkan output data tekstual dan spatial untuk melihat kondisi ketahanan pangan di wilayah penelitian.

Kondisi ketahanan pangan di Kabupaten Sleman dengan tingkatan sangat tahan pangan berada di Kecamatan Cangkringan dan yang berada dalam kategori sangat rawan pangan di Kecamatan Sleman dan Moyudan. Berdasarkan indikator yang dihitung secara statistik; tingkat akses terhadap pangan, kesesuaian penggunaan tanah dan ketersediaan tanah valid dan reliabilitas dijadikan aspek penilaian ketahanan pangan. Data neraca yang digunakan dalam analisis ketahanan pangan adalah data kawasan budidaya pertanian dan non-pertanian untuk menentukan nilai indeks luas lahan pertanian dalam penentuan kerentanan pangan. Berdasarkan analisis dengan menggunakan indeks penentu kerawanan pangan didapatkan bahwa kondisi 15 Kecamatan di Kabupaten Sleman masuk ke dalam kategori tahan pangan dan 2 Kecamatan yaitu Depok dan Sleman masuk ke dalam kategori daerah berpotensi rawan pangan.

Kata Kunci: Neraca, Penggunaan Tanah, Budidaya, Pertanian, Ketahanan Pangan Pokok Wilayah

\section{PENGANTAR}

Kebijakan pangan merupakan kebijakan yang strategis mengingat bahwa pangan merupakan kebutuhan primer manusia. Kebijakan peningkatan produksi pangan memiliki kontribusi terhadap pembangunan ekonomi karena pangan memiliki dukungan pembangunan ekonomi dari kontribusi produksi, kontribusi pasar dan kontribusi faktor produksi serta kontribusi devisa Habbakkuk (1970:10). Prioritas pembangunan pertanian di Indonesia penting karena sebagai negara yang beriklim tropis dan sebagian besar penduduk yang masih banyak tinggal di pedesaan, penguatan pembangunan pangan dapat mendorong peningkatan pendapatan masyarakat selain di sektor industri.

Laju peningkatan jumlah rumah tangga petani di DIY tidak sebanding dengan luas penguasaan lahan. Rata-rata luas kepemilikan lahan bagi petani adalah 0,30 hektar. Kondisi ini mengakibatkan meningkatnya jumlah petani gurem dan buruh tani (tuna kisma) di DIY. Hal ini berdampak pada sulitnya upaya meningkatkan kesejahteraan petani dan pengentasan kemiskinan di kawasan perdesaan. Di sisi lain, proses urbanisasi yang tidak terkendali berdampak pada meluasnya aktivitas-aktivitas perkotaan yang makin mendesak aktivitas-aktivitas pertanian di kawasan perdesaan yang berbatasan langsung dengan perkotaan.

Persoalan ini harus dicarikan solusi pemecahannya karena melihat juga dampak yang ditimbulkan dari alih fungsi lahan ini dapat merugikan petani di Kabupaten Sleman dan terancamnya produksi tanaman pangan. Adanya alih fungsi lahan pertanian khususnya lahan sawah akan mempengaruhi produksi beras sebagai makanan pokok masyarakat Indonesia sehingga akan berpengaruh terhadap ketahanan pangan. Akibatnya alih fungsi penggunaan tanah tidak dapat dicegah, dimana sawah-sawah pertanian subur dan sawah beririgasi teknis di sekitarnya semakin lama semakin luas dialihgunakan menjadi tempattempat kegiatan ekonomi dan pemukiman.

Tujuan dilakukan penelitian ini adalah untuk melihat kondisi sebaran penatagunaan tanah yang terkena dampak pada meningkatnya 
luas pekarangan dan permukiman di Kabupaten Sleman, menganalisis perimbangan (neraca) penggunaan tanah pertanian dan dampaknya terhadap ketahanan pangan pokok wilayah Kabupaten Sleman, dan mengetahui tingkat kerawanan pangan untuk mendukung analisis ketahanan pangan pokok wilayah di wilayah Kabupaten Sleman.

\section{PEMBAHASAN}

\section{Ketahanan Pangan Pokok}

Rosset (2003:2) telah memberikan ilustrasi yang sangat baik mengenai negaranegara yang melakukan kedaulatan pangan dengan kondisi ketahanan pangannya. Negaranegara kategori A (USA, Canada, Australia, Brunei) memiliki kapasitas pangan yang paling kuat karena memiliki kondisi pangan ideal dimana mereka mampu berkedaulatan pangan tetapi sekaligus juga memiliki ketahanan pangan yang kuat sedangkan negara C seperti Singapura, Norwegia dan Jepang, negara tersebut tidak berdaulat pangan tetapi memiliki fondasi ketahanan pangan yang jauh lebih kuat dari negara-negara kategori B seperti Indonesia, Filipina dan Myanmar (tabel 1).

Ketersediaan tanah pertanian merupakan faktor utama untuk menciptakan ketahanan pangan. Permasalahan ketersediaan tanah pertanian yang tidak mencukupi, tidak terinventarisasinya jumlah lahan pertanian, penyusutan lahan pertanian dan kurangnya dukungan terhadap pengembangan lahan pertanian menyebabkan Indonesia berada pada kondisi yang rawan pangan. Seiring dengan peningkatan jumlah penduduk dan perkembangan struktur perekonomian, kebutuhan lahan untuk kegiatan non-pertanian cenderung terus meningkat. Kecenderungan tersebut menyebabkan alih fungsi lahan pertanian sulit dihindari. Beberapa kasus menunjukkan jika di suatu lokasi terjadi alih fungsi lahan, maka dalam waktu yang tidak lama lahan di sekitarnya juga beralih fungsi secara progresif. Hal tersebut disebabkan oleh dua faktor, yaitu: (1). Sejalan dengan pembangunan kawasan perumahan atau industri di suatu lokasi alih fungsi lahan, maka aksesibilitas di lokasi tersebut menjadi semakin kondusif untuk pengembangan industri dan pemukiman yang akhirnya mendorong meningkatnya permintaan lahan oleh investor lain atau spekulan tanah sehingga harga lahan di sekitarnya meningkat. (2). Peningkatan harga lahan selanjutnya dapat merangsang petani lain di sekitarnya untuk menjual lahan (Iqbal, 2007:120).

Pangan merupakan kebutuhan dasar utama bagi manusia yang harus dipenuhi setiap saat. Hak untuk memperoleh pangan merupakan bagian dasar hak asasi manusia. Mengutip dari UU 18/2012 tentang Pangan, bahwa pangan adalah segala sesuatu yang

Tabel 1

Contoh Negara Berdaulat Pangan dan Tahan Pangan

\begin{tabular}{|c|c|c|}
\hline & Tahan Pangan & Tidak Tahan Pangan \\
\hline & A & B \\
\hline Berdaulat Pangan & $\begin{array}{l}\text { Contoh : USA, Kanada, Australia, } \\
\text { Brunei, dsb. }\end{array}$ & Contoh : Myanmar, Indonesia, Filipina \\
\hline \multirow{2}{*}{ Tidak Berdaulat Pangan } & $\mathrm{C}$ & $\mathrm{D}$ \\
\hline & Contoh : Norwegia, Jepang, Singapura & Contoh : Malawi, Eritrea, Kenya, Kongo, East Timor \\
\hline
\end{tabular}

Sumber : Rosset, 2003:2 
Samudra Ivan Supratikno, Armaidy Armawi, dan Djaka Marwasta -- Pemanfaatan Neraca Penatagunaan Tanah Dalam Mendukung Penyusunan Sistem Informasi Ketahanan Pangan Pokok Wilayah (Studi Di Kabupaten Sleman, Daerah Istimewa Yogyakarta)

berasal dari sumber hayati produk pertanian, perkebunan, kehutanan, perikanan, peternakan, perairan, dan air, baik yang diolah maupun tidak diolah yang diperuntukkan sebagai makanan atau minuman bagi konsumsi manusia, termasuk bahan tambahan Pangan, bahan baku Pangan, dan bahan lainnya yang digunakan dalam proses penyiapan, pengolahan, dan/atau pembuatan makanan atau minuman. Selanjutnya disebutkan bahwa jenis pangan dibagi menjadi 4 kelompok, yaitu: (1). Pangan Pokok adalah pangan yang diperuntukkan sebagai makanan utama sehari-hari sesuai dengan potensi sumber daya dan kearifan lokal; (2). Pangan Lokal adalah makanan yang dikonsumsi oleh masyarakat setempat sesuai dengan potensi dan kearifan lokal; (3). Pangan Segar adalah pangan yang belum mengalami pengolahan yang dapat dikonsumsi langsung dan/atau yang dapat menjadi bahan baku pengolahan data; (4). Pangan Olahan adalah makanan atau minuman hasil proses dengan cara atau metode tertentu dengan atau tanpa bahan tambahan.

Ketahanan pangan Webb (2003:140) merupakan basis utama dalam wewujudkan ketahanan ekonomi, ketahanan nasional yang berkelanjutan. Ketahanan pangan merupakan sinergi dan interaksi utama dari subsistem ketersediaan, distribusi dan konsumsi, dimana dalam mencapai ketahanan pangan dapat dilakukan alternatif pilihan apakah kedaulatan atau kecukupan.

Dalam bidang pertanahan penyediaan lahan pangan untuk mencapai ketahanan pangan berkaitan erat dengan aspek yuridisnya. Amanat tersebut dituangkan dalam Undang-Undang Nomor 41 Tahun 2009 tentang Perlindungan Lahan Pertanian Pangan Berkelanjutan (PLP2B) bahwa Indonesia sebagai negara agraris perlu menjamin penyediaan lahan pertanian pangan secara berkelanjutan sebagai sumber pekerjaan dan penghidupan yang layak bagi kemanusiaan dengan mengedepankan prinsip kebersamaan, efisiensi berkeadilan, berkelanjutan, berwawasan lingkungan, dan kemandirian, serta dengan menjaga keseimbangan, kemajuan, dan kesatuan ekonomi nasional.

\section{Tata Guna Tanah}

Tata Guna Tanah (land use) adalah pengaturan penggunaan tanah yang digunakan bukan hanya dipermukaan bumi daratan namun juga mengenai penggunaan tanah di lautan (Jayadinata, 1999:10). Dalam tata guna tanah dikenal istilah penggunaan, aguna (tidak digunakan), wyaguna (penggunaan yang salah) atau alpaguna, dan tuna-guna (penggunaan yang kurang benar). Dalam hal penatagunaan tanah harus dipenuhi unsur sumber daya manusia dan sumber daya lainnya untuk menciptakan harmonisasi. Penatagunaan tanah selain dalam kerangka sebesar-besar kemakmuran rakyat, juga harus memperhatikan kewajiban pemeliharaan tanah dalam arti menjaga dan menambah kesuburannya, serta mencegahnya dari kerusakan. Tata guna tanah merupakan suatu konsep yang berkaitan dengan penataan tanah secara maksimal, sebab konsep tata guna tanah selain mengatur mengenai persediaan, penggunaan terhadapbumi, air, dan ruang angkasa, juga terhadap tanggung jawab pemeliharaan tanah, termasuk di dalamnya menjaga kesuburannya. Muchsin dan Imam Koeswahyono, dalam Santoso (2005:247), menyatakan ada 4 unsur esensial dalam penatagunaan tanah, yaitu: (1). Adanya serangkaian kegiatan/aktivitas, yaitu pengumpulan data lapangan tentang 
penggunaan, penguasaan, kemampuan fisik, pembuatan rencana/pola penggunaan tanah, penguasaan dan keterpaduan yang dilakukan secara integral dan koordinasi dengan instansi lain. (2). Dilakukan secara berencana dalam arti harus sesuai dengan prinsip: Lestari, Optimal, Serasi, dan Seimbang (LOSS). (3). Adanya tujuan yang hendak dicapai, yaitu sejalan dengan tujuan pembangunan untuk sebesar-besar kemakmuran rakyat. (4). Harus terkait langsung dengan peletakan proyek pembangunan dengan memperhatikan DSP (Daftar Skala Prioritas).

Penggunaan tanah menunjukkan pengaruh budaya yang besar dalam adaptasi ruang dimana ruang merupakan simbol dari nilai-nilai sosial. Menurut Steigenga (1964:121) menggolongkan tanah dengan beberapa nilai yaitu: (1). Nilai Keuntungan, yang dihubungkan dengan tujuan ekonomi, dan yang dapat dicapai dengan jual-beli tanah dipasar bebas. (2). Nilai Kepentingan Umum, yang berhubungan dengan pengaturan untuk masyarakat umum dalam perbaikan kehidupan masyarakat. (3). Nilai Sosial, yang merupakan hal dasar bagi kehidupan dan yang dinyatakan oleh penduduk dengan perilaku yang berhubungan dengan pelesatarian, tradisi, kepercayaan dan sebagainya.

Kebijakan penatagunaan tanah adalah pedoman umum penatagunaan tanah di daerah yang meliputi kebijakan penguasaan, penggunaan dan pemanfaatan tanah di kawasan lindung dan kawasan budidaya. Kebijakan penatagunaan tanah merupakan implementasi dari rencana tata ruang, karena dalam kenyataannya bidang-bidang tanah telah dikuasai dan atau dimiliki oleh orang-orang dan atau badan hukum dalam bentuk hubungan hukum sesuai dengan perundang-undangan yang berlaku maupun ketentuan hukum adat atau ulayat. Analisis penatagunaan tanah terdiri dari analisis perubahan penggunaan tanah, analisis kesesuaian penggunaan tanah terhadap rencana tata ruang, analisis ketersediaan tanah dan analisis ketersediaan tanah untuk komoditas tertentu.

\section{Neraca Penatagunaan Tanah}

Santoso (2005:60) menyatakan bahwa neraca penatagunaan tanah pada dasarnya merupakan program operasionalisasi pemanfaatan ruang dalam upaya mewujudkan pola ruang dan struktur ruang wilayah dan kawasan strategis. Sehubungan dengan telah diundangkannya Peraturan Pemerintah Nomor 16 Tahun 2004 pada tanggal 10 Mei 2004 tentang Penatagunaan Tanah, berarti menjawab perintah Pasal 14 Juncto Pasal 15 Undang-Undang Nomor 5 Tahun 1960 bahwa pengaturan tentang kewajiban pemerintah untuk menyusun perencanaan penggunaan, penguasaan, dan pemilikan tanah dalam suatu peraturan pemerintah terjawab setelah melewati kurun waktu 44 tahun. Merujuk pada peraturan pemerintah tersebut, pengertian neraca penatagunaan tanah adalah perimbangan antara ketersediaan tanah dan kebutuhan penguasaan, penggunaan dan pemanfaatan tanah menurut fungsi kawasan Rencana Tata Ruang Wilayah (RTRW).

Dalam melaksanakan amanat tersebut dibutuhkan perimbangan atau neraca untuk dapat menganalisisnya sebagaimana dituangkan dalam Peraturan Pemerintah Nomor 16 Tahun 2004. Peraturan Pemerintah Nomor 16 Tahun 2004 tersebut mengenalkan pentingnya penyusunan neraca tanah yang digunakan dalam penatagunaan tanah, walau hingga saat ini belum ditindaklanjuti 
Samudra Ivan Supratikno, Armaidy Armawi, dan Djaka Marwasta -- Pemanfaatan Neraca Penatagunaan Tanah Dalam Mendukung Penyusunan Sistem Informasi Ketahanan Pangan Pokok Wilayah (Studi Di Kabupaten Sleman, Daerah Istimewa Yogyakarta)

dengan pengaturan yang lebih mendalam. Amanat lain yang diperintahkan dalam undang- undang tersebut juga mencantumkan bahwa pengembangan penatagunaan tanah harus melalui penyelenggaraan kegiatan dan penyusunan neraca penatagunaan tanah. Dengan menggunakan neraca maka penataan dan pengaturan pertanahan dapat dicari alternatif yang lebih baik dengan mengusahakan lokasi yang sesuai dengan kebutuhan dan sesuai dengan peraturan dan perundangan (asas legal formal). Penggunaan dan pemanfaatan tanah yang tidak sesuai dengan tata ruang wilayah tidak dapat diperluas atau dikembangkan. Penguasaan, penggunaan dan pemanfaatan tanah yang tidak sesuai dengan rencana tata ruang wilayah, disesuaikan melalui penyelenggara penatagunaan tanah. Penyusunan neraca penatagunaan tanah meliputi: (1). Penyajian neraca perubahan penggunaan dan pemanfaatan tanah dan sumber daya alam lain pada rencana tata ruang wilayah. (2). Penyajian neraca kesesuaian penggunaan dan pemanfaatan tanah dan sumber daya alam lain pada rencana tata ruang wilayah. (3). Penyajian ketersediaan tanah dan sumber daya alam lain dan penetapan prioritas penyediaannya pada rencana tata ruang wilayah.

\section{Kondisi Neraca Penatagunaan Tanah Kabupaten Sleman}

Penyusutan lahan pertanianinimerupakan salah satu persoalan serius di Sleman. Terlebih jika melihat potensi Kabupaten Sleman sebagai penyangga sekitar 60 persen, dari kebutuhan pangan masyarakat Daerah Istimewa Yogyakarta. Selama 14 tahun terakhir ini telah terjadi fenomena perkembangan permukiman dengan pengurangan lahan-lahan pertanian.
Data menunjukkan bahwa di tahun 2007 alih fungsi lahan pertanian di Kecamatan Kalasan, Sleman rata-rata mencapai 2,5 persen pertahun. Kondisi tersebut dipertegas oleh data dari Dinas Pertanian dan Kehutanan Kabupaten Sleman menyebutkan,bahwa pada tahun 2005 lahan pertanian mencapai 23.191 hektar dengan lahan pekarangan dan bangunan 18.986 hektar, kemudian 2006 lahan pertanian turun menjadi 23.121 hektar dengan lahan pekarangan dan bangunan 19.034 hektar. Hingga kurun waktu 2014 lahan pertanian kembali menyusut menjadi sampai dengan 23.062 hektar, sedangkan lahan pekarangan dan bangunan meningkat menjadi 19.343 hektar.

Beberapa kasus menunjukkan jika di suatu lokasi terjadi alih fungsi lahan, maka dalam waktu yang tidak lama lahan di sekitarnya juga beralih fungsi secara progresif. Meningkatnya alih fungsi tentunya membutuhkan strategi untuk melakukan pengendalian. Dalam rangka pengendalian penggunaan tanah untuk pertanian pemerintah daerah Sleman telah memberlakukan mengenai berbagai izin yaitu izin lokasi penggunaan daerah komersil, izin pengeringan sawah untuk permukiman dan izin mendirikan bangunan. Hal ini dimaksudkan untuk mengendalikan perubahan penggunaan tanah untuk pertanian terutama untuk mempertahankan sawah irigasi dimana sawah tersebut menghasilkan padi sebagai komoditas pangan untuk penduduknya. Bersumber pada publikasi neraca Penatagunaan Tanah Propinsi DIY 2012, secara garis besar terdapat perubahan penggunaan tanah pada tahun 2010 hingga tahun 2014. Tabel 2 berikut merupakan hasil analisis dari SIG dengan penerapan untuk pengukuran atau measurement. Luasan dari tahun 2010 sampau 
pada tahun 2014 dapat dihitung menggunakan aplikasi SIG dengan presisi. Hasil pengolahan data digambarkan dalam Tabel 2

Berdasar tabel 2 dapat dilihat bahwa perubahan penggunaan tanah di Kabupaten Sleman ada yang besar dan ada pula perubahan yang sangat kecil. Perubahan penggunaan tanah tersebut ada yang berupa penambahan jumlah dan ada juga yang pengurangan jumlah penggunaan tanah. Tanda minus (-) berarti bahwa terdapat pengurangan penggunaan tanah pada tahun 2014, sedangkan tanda plus $(+)$ berarti ada penambahan penggunaan tanah pada tahun 2014.

Tabel 2

Rekapitulasi Perubahan Penggunaan Tanah Kabupaten Sleman Tahun 2010 - 2014

\begin{tabular}{|c|c|c|c|c|c|c|}
\hline \multirow[b]{2}{*}{ No } & \multirow[b]{2}{*}{ Penggunaan Tanah } & \multicolumn{2}{|c|}{ Luas (Ha) } & \multicolumn{3}{|c|}{ Perubahan Penggunaan Tanah } \\
\hline & & Tahun 2010 & Tahun 2014 & Luas (Ha) & Perubahan (\%) & $\begin{array}{l}\text { Rata-rata/ } \\
\text { tahun (Ha) }\end{array}$ \\
\hline 1 & Bandara & 187,334 & 255,989 & 68,655 & 0,119 & 17,164 \\
\hline 2 & Batuan Pasir & 6,237 & $1.004,142$ & 997,905 & 1,732 & 249,476 \\
\hline 3 & Belukar/Semak & $1.254,831$ & $1.905,098$ & 650,267 & 1,129 & 162,567 \\
\hline 4 & Candi Prambanan & 32,190 & 32,190 & 0,000 & 0,000 & 0,000 \\
\hline 5 & Candi Sambisari & 2,102 & 2,102 & 0,000 & 0,000 & 0,000 \\
\hline 6 & Danau & 1,307 & 1,307 & 0,000 & 0,000 & 0,000 \\
\hline 7 & Emplasemen & 13,523 & 322,503 & 308,980 & 0,536 & 77,245 \\
\hline 8 & Hutan & 937,067 & 862,415 & $-74,652$ & $-0,130$ & $-18,663$ \\
\hline 9 & Industri & 20,689 & 24,626 & 3,937 & 0,007 & 0,984 \\
\hline 10 & Jalan & $1.247,539$ & $1.247,495$ & $-0,044$ & 0,000 & $-0,011$ \\
\hline 11 & Jasa Kesehatan & 8,166 & 8,166 & 0,000 & 0,000 & 0,000 \\
\hline 12 & Jasa Pendidikan & 26,672 & 27,623 & 0,951 & 0,002 & 0,238 \\
\hline 13 & Kantor Pemerintah & 9,137 & 9,137 & 0,000 & 0,000 & 0,000 \\
\hline 14 & Kebun Campuran & $5.322,355$ & $5.367,808$ & 45,453 & 0,079 & 11,363 \\
\hline 15 & Kebun Salak & 2,042 & $1.063,668$ & $1.061,626$ & 1,843 & 265,407 \\
\hline 16 & Kolam Air Tawar & 0,724 & 101,041 & 100,317 & 0,174 & 25,079 \\
\hline 17 & Kuburan/Makam & 5,392 & 6,454 & 1,062 & 0,002 & 0,266 \\
\hline 18 & Lapangan Golf & 6,590 & 42,960 & 36,370 & 0,063 & 9,093 \\
\hline 19 & Lapangan Olah Raga & 182,054 & 140,027 & $-42,027$ & $-0,073$ & $-10,507$ \\
\hline 20 & Pasar & 4,795 & 5,565 & 0,770 & 0,001 & 0,193 \\
\hline 21 & Pasir darat & 56,646 & 0,000 & $-56,646$ & $-0,098$ & $-14,162$ \\
\hline 22 & Pemukiman/Kampung & $14.828,815$ & $17.095,630$ & $2.266,815$ & 3,935 & 566,704 \\
\hline 23 & Perumahan & 1,165 & 248,925 & 247,760 & 0,430 & 61,940 \\
\hline 24 & Rumput & 976,816 & 193,010 & $-783,806$ & $-1,360$ & $-195,951$ \\
\hline 25 & Sawah Irigasi & $25.952,593$ & $23.244,007$ & $-2.708,586$ & $-4,701$ & $-677,146$ \\
\hline 26 & Sawah Tadah Hujan & $1.001,322$ & 450,637 & $-550,685$ & $-0,956$ & $-137,671$ \\
\hline 27 & Selter Merapi & 0,000 & 30,589 & 30,589 & 0,053 & 7,647 \\
\hline 28 & Stadion & 15,302 & 24,631 & 9,329 & 0,016 & 2,332 \\
\hline 29 & Sungai & 296,542 & 296,561 & 0,019 & 0,000 & 0,005 \\
\hline 30 & Tanah Berbatu & 304,146 & 285,550 & $-18,596$ & $-0,032$ & $-4,649$ \\
\hline 31 & Tanah Tandus & 6,338 & 6,338 & 0,000 & 0,000 & 0,000 \\
\hline 32 & Tanah Terbuka & 31,836 & 3,652 & $-28,184$ & $-0,049$ & $-7,046$ \\
\hline 33 & Tanah kosong (diperuntukkan) & 0,000 & 4,008 & 4,008 & 0,007 & 1,002 \\
\hline 34 & Tegalan & $4.869,895$ & $3.293,297$ & $-1.576,598$ & $-2,736$ & $-394,149$ \\
\hline 35 & Terminal & 0,903 & 0,903 & 0,000 & 0,000 & 0,000 \\
\hline 36 & Waduk & 0,647 & 5,655 & 5,008 & 0,009 & 1,252 \\
\hline
\end{tabular}

Sumber : Data Neraca Penatagunaan TanahTahun 2014 
Konversi penggunaan atau perubahan penggunaan tanah di Kabupaten Sleman selama kurun waktu tahun 2010 sampai dengan tahun 2014 memperlihatkan penambahan yang signifikan pada penggunaan tanah tertentu, yaitu pada penggunaan permukiman/ kampung, kebun salak, batuan pasir, belukar dan semak, emplasemen, perumahan, kolan air tawar. Penambahan luasan paling luas adalah pada jenis penggunaan tanah permukiman/ kampung yaitu sebesar 566,704 hektar selama periode tahun 2010 sampai dengan tahun 2014. Sementara itu terjadi beberapa penggunaan tanah yang memiliki luasan lebih sempit pada tahun 2014 antara lain sawah irigasi, tegalan, rumput dan sawah tadah hujan. Pengurangan luasan paling banyak adalah pada jenis penggunaan tanah sawah irigasi yaitu berkurang 677,146 hektar selama periode tahun 2010 sampai dengan tahun 2014. Perubahan ini tentunya bisa menjadi bahan masukan untuk pengambilan kebijakan dalam memnentukan kawasan pertanian. Berkurangnya penggunaan tanah untuk pertanian ini tentunya harus diwaspadai karena dapat berpengaruh terhadap penyediaan lahan untuk menanam komoditas pangan.

Perubahan luas penggunaan tanah di atas 3 persen terjadi pada penambahan pemukiman/kampung, seperti gambar di samping menunjukkan salah satu contoh sawah irigasi dengan luasan kecil yang berada di antara pemukiman di Kecamatan Kalasan. Dapat dikatakan bahwa pemukiman tersebut dahulu merupakan sawah. Tabel 2 di atas menunjukkan adanya pengurangan luas sawah irigasi di Kabupaten Sleman yang salah satunya yang menonjol berubah menjadi pemukiman atau perumahan. Pengurangan luas penggunaan sawah irigasi dari tahun
2010 sampai dengan tahun 2014 sebesar 4,701 persen dari luas wilayah Kabupaten Sleman. Pengurangan jumlah sebesar 2,736 persen terjadi pada penggunaan tanah tegalan. Penggunaan tegalan di Kabupaten Sleman ini juga ada yang berubah menjadi kebun salak yang saat ini di Kabupaten Sleman luasnya bertambah sebesar 1,843 persen.

Penambahan luas penggunaan tanah apabila dibandingkan dengan tahun 2010 terjadi pada penggunaan tanah bandara, batuan pasir, belukar/semak, emplasemen, industri, jasa pendidikan, kebun campuran, kebun salak, kolam air tawar, lapangan golf, pasar, pemukiman/kampung, perumahan, selter Merapi, stadion, tanah kosong (diperuntukkan), dan waduk. Perubahan penggunaan tanah yang sangat kecil terjadi pada penggunaan tanah jalan, jasa pendidikan, pasar dan sungai. RTRW Kabupaten Sleman yang digunakan dalam analisis penyusunan neraca penatagunaan tanah ini adalah rencana tata ruang wilayah berdasarkan Rencana Tata Ruang Wilayah Kabupaten Sleman Tahun 2011 - 2031. Kesesuaian penggunaan tanah dalam perencanaan kawasan pertanian untuk ketahanan pangan menjadi bahan masukan dalam melakukan pengendalian lahan pertanian.

Arahan Fungsi RTRW yang dominan di Kabupaten Sleman ada 3 macam, yaitu: (1). Kawasan permukiman 38 persen, (2). Kawasan pertanian tanaman pangan 36,6 persen, dan (3) Kawasan holtikultura sebanyak 15,9 persen. Sementara itu sisanya untuk arahan fungsi lainnya, dimana paling kecil wilayahnya adalah arahan fungsi untuk industri yaitu sebesar 0,4 persen dari total wilayah Kabupaten Sleman. Lebih jelasnya lagi mengenai pembagian proporsi dari masing-masing arahan fungsi 
RTRW di Kabupaten Sleman dapat dilihat pada gambar 1.

Kesesuaian penggunaan tanah dengan rencana tata ruang merupakan analisis relasi jenis penggunaan tanah saat ini dengan kondisi ideal yang akan diwujudkan, yang tercermin dalam rencana penataan ruang. Dalam ketahanan pangan kesesuaian penggunaan tanah digunakan untuk mengetahui kecocokan antara penggunaan tanah untuk komoditas pangan dengan tata ruang dan keadaan tanahnya. Penata ruang bertujuan untuk mengarahkan penggunaan tanah agar sesuai dengan kondisi lingkungannya dengan harapan dapat menghasilkan produk yang optimal dan penataan agar memiliki keteraturan. Di Kabupaten Sleman untuk mengendalikan pemanfaatan ruang salah satu instrumen yang digunakan adalah izin peruntukan penggunaan tanah (IPPT). Namun pada kenyataan di lapangan masih banyak dijumpai perubahan penggunaan tanah tanpa izin dari pemerintah daerah dan bahkan melanggar rencana tata ruang yang ada. Analisis kesesuaian tataruang dengan neraca menjadi input pertimbangan dalam menentukan prioritas dan rencana tata ruang, karena tentunya seiring dengan perubahan-perubahan dan trend pertumbuhan yang terjadi. Dalam RTRW Kabupaten Sleman tersebut dibagi menjadi 9 kawasan. Pembagian arahan fungsi kawasan pada RTRW ini terdiri dari kawasan jalan, holtikultura, hutan rakyat, industri, permukiman, pertahanan dan keamanan, kawasan pertanian tanaman pangan, sungai dan kawasan Taman Nasional Gunung Merapi. Sedangkan rincian luas wilayah tiap kecamatan di Kabupaten Sleman menurut arahan fungsi kawasan dalam RTRW Kabupaten Sleman

Tabel 3 menunjukkan bahwa penggunaan tanah di Kabupaten Sleman saat ini ada yang sesuai dengan arahan fungsi kawasan dalam RTRW dan ada juga yang tidak sesuai dengan arahan fungsi kawasan dalam RTRW. Berdasarkan analisis spasial yang telah digunakan ketidaksesuaian yang paling besar adalah pada kawasan permukiman, yaitu mencapai 12,437 persen, sedangkan

Gambar 1

Rencana Tata Ruang Kabupaten Sleman Tahun 2011 - 2032

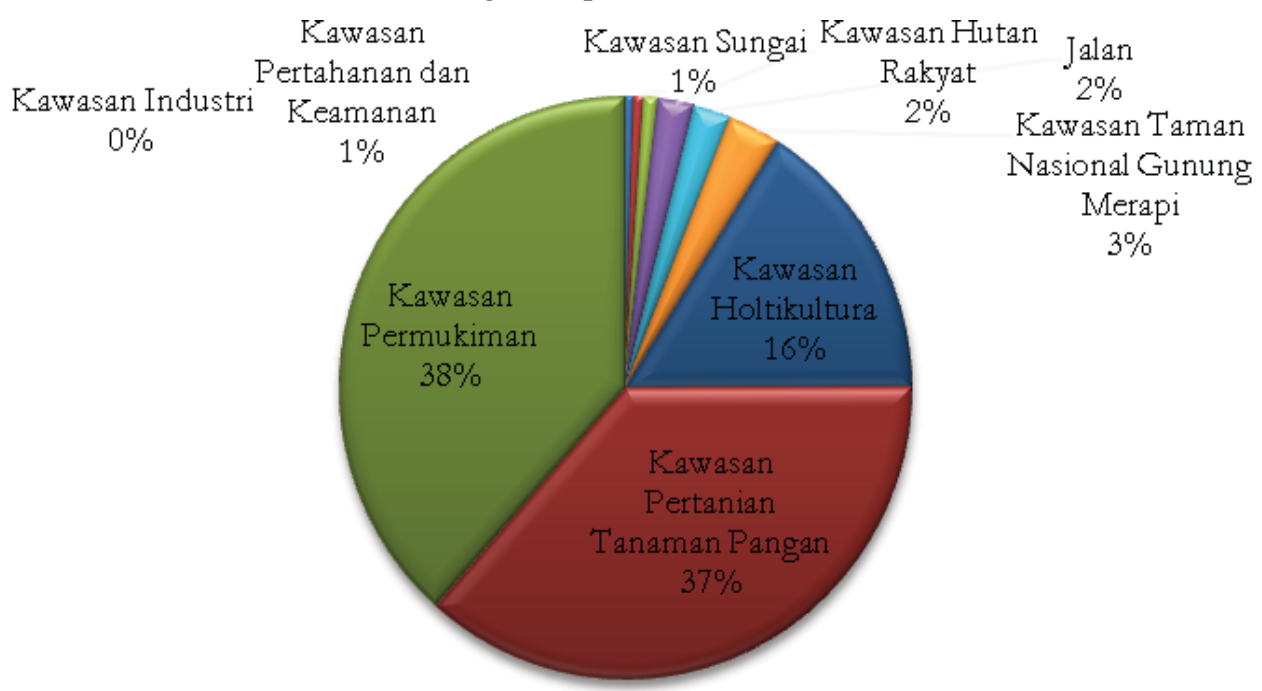

Sumber : RTRW Kabupaten Sleman (Perda Kabupaten Sleman No. 12 Tahun 2012) dan Perhitungan Digital Data Neraca Penatagunaan Tanah Tahun 2014 
Samudra Ivan Supratikno, Armaidy Armawi, dan Djaka Marwasta -- Pemanfaatan Neraca Penatagunaan Tanah Dalam Mendukung Penyusunan Sistem Informasi Ketahanan Pangan Pokok Wilayah (Studi Di Kabupaten Sleman, Daerah Istimewa Yogyakarta)

Tabel 3

Kesesuaian Penggunaan Tanah dengan Rencana Tata Ruang Wilayah Kabupaten Sleman

\begin{tabular}{llrrrr}
\hline \multirow{2}{*}{ No. } & \multirow{2}{*}{ Arahan Fungsi Kawasan dalam RTRW } & \multicolumn{3}{c}{ Kesesuaian Penggunaan Tanah dengan RTRW } \\
\cline { 3 - 6 } & & \multicolumn{2}{c}{ Sesuai } & \multicolumn{2}{c}{ Tidak Sesuai } \\
\cline { 3 - 6 } & Jalan & $1.239,505$ & 2,151 & 0,000 & 0,000 \\
2 & Kawasan Hortikultura & $6.071,330$ & 10,538 & $3.134,533$ & 5,441 \\
3 & Kawasan Hutan Rakyat & 893,752 & 1,551 & 260,042 & 0,451 \\
4 & Kawasan Industri & 50,486 & 0,088 & 209,799 & 0,364 \\
5 & Kawasan Permukiman & $14.991,871$ & 26,021 & $7.165,578$ & 12,437 \\
6 & Kawasan Pertahanan dan Keamanan & 377,062 & 0,654 & 97,090 & 0,169 \\
7 & Kawasan Pertanian Tanaman Pangan & $19.991,753$ & 34,700 & $1.088,729$ & 1,890 \\
8 & Kawasan Sungai & 213,145 & 0,370 & 100,660 & 0,175 \\
9 & Kawasan Taman Nasional Gunung Merapi & $1.686,343$ & 2,927 & 42,033 & 0,073 \\
\hline \multicolumn{2}{c}{ Total } & $45.515,247$ & 79,001 & $12.098,465$ & 20,999 \\
\hline
\end{tabular}

Sumber : RTRW Kabupaten Sleman dan Data Neraca Penatagunaan Tanah Tahun 2014 dan hasil pengolahan studio

ketidaksesuaian yang persentasenya di bawahnya adalah pada kawasan hortikultura, yaitu sebesar 5,441 persen, selanjutnya kawasan pertanian tanaman pangan ketidaksesuaian sebesar 1,890 persen dan kawasan yang lain ketidaksesuaian di bawah 1,00 persen. Ketidaksesuaian ini jika tidak dikendalikan maka akan mengancam keberadaan lahan untuk pertanian.

\section{Prioritas Ketersediaan Tanah}

Analisis ketersediaan tanah terdiri dari 2 analisis, yaitu analisis prioritas ketersediaan tanah dan analisis ketersediaan tanah kegiatan atau komoditas tertentu. Prioritas ketersediaan tanah ini diperoleh dari overlay antara peta penggunaan tanah yang baru dan peta gambaran umum penguasaan tanah. Penggunaan tanah yang belum intensif (non budidaya) dan belum ada penguasaan tanah skala besar, dikategorikan tersedia indikatif. Penyusunan prioritas ketersediaan tanah merupakan analisis membutuhkan kecermatan dalam melihat wilayah, karena layer yang mendukung dalam tahapan ini lebih banyak, yaitu peta kesesuaian tanah dengan RTRW, peta penggunaan tanah, peta gambaran umum penguasaan tanah dan peta RTRW. Tanah-tanah tersedia indikatif yang terletak pada kawasan lindung dikategorikan sebagai tersedia terbatas untuk fungsi lindung. Sedangkan tanah-tanah tersedia indikatif yang terletak pada kawasan budidaya dapat digunakan untuk berbagai kegiatan sesuai dengan arahan tata ruang. Pembagian ketersediaan tersebut dimaksudkan untuk perencanaan penetapan kawasan pertanian dalam RTRW untuk ketahanan pangan.

Prioritas ketersediaan tanah di Kabupaten Sleman ini lebih lengkap dapat dilihat pada tabel 4 Prioritas Ketersediaan Tanah.

Berdasarkan tabel 4 dapat dilihat bahwa tanah di Kabupaten Sleman ini sebagian kecil tersedia untuk kegiatan budidaya, kemudian tersedia bersyarat untuk kegiatan berfungsi lindung, selanjutnya adalah sudah ada penguasaan tanah, namun penggunaan tanah tidak sesuai dengan fungsi kawasan dan luasan yang terbesar adalah klasifikasi sudah ada penguasaan tanah dan penggunaan tanah sesuai dengan fungsi kawasan.

Dalam memudahkan membaca hasil output tersebut disajikan gambar 2 . 
Tabel 4

Prioritas Ketersediaan Tanah

\begin{tabular}{|c|c|c|c|}
\hline No & Klasifikasi Ketersediaan Tanah & Luas (Ha) & $\%$ \\
\hline \multirow[t]{3}{*}{ I. } & Tersedia & & \\
\hline & 1. Tersedia untuk kegiatan budidaya sesuai tata ruang & 307,107 & 0,533 \\
\hline & 2. Tersedia bersyarat untuk kegiatan berfungsi lindung & $2.327,937$ & 4,041 \\
\hline \multirow[t]{3}{*}{ II. } & Telah ada penguasaan dan/atau penggunaan tanah & & \\
\hline & $\begin{array}{l}\text { 1. Tersedia dalam rangka penyesuaian penggunaan tanah (sudah ada } \\
\text { penguasaan tanah, namun penggunaan tanah tidak sesuai dengan RTRW }\end{array}$ & $11.793,544$ & 20,470 \\
\hline & $\begin{array}{l}\text { 2. Tersedia dalam rangka optimalisasi penggunaan tanah (sudah ada } \\
\text { penguasaan tanah dan penggunaan tanah sesuai dengan RTRW }\end{array}$ & $43.185,124$ & 74,956 \\
\hline
\end{tabular}

Sumber : Data Neraca Penatagunaan Tanah Tahun 2014

Gambar 2

Prioritas Ketersediaan Tanah (Ha) Setiap kecamatan di Kabupaten Sleman

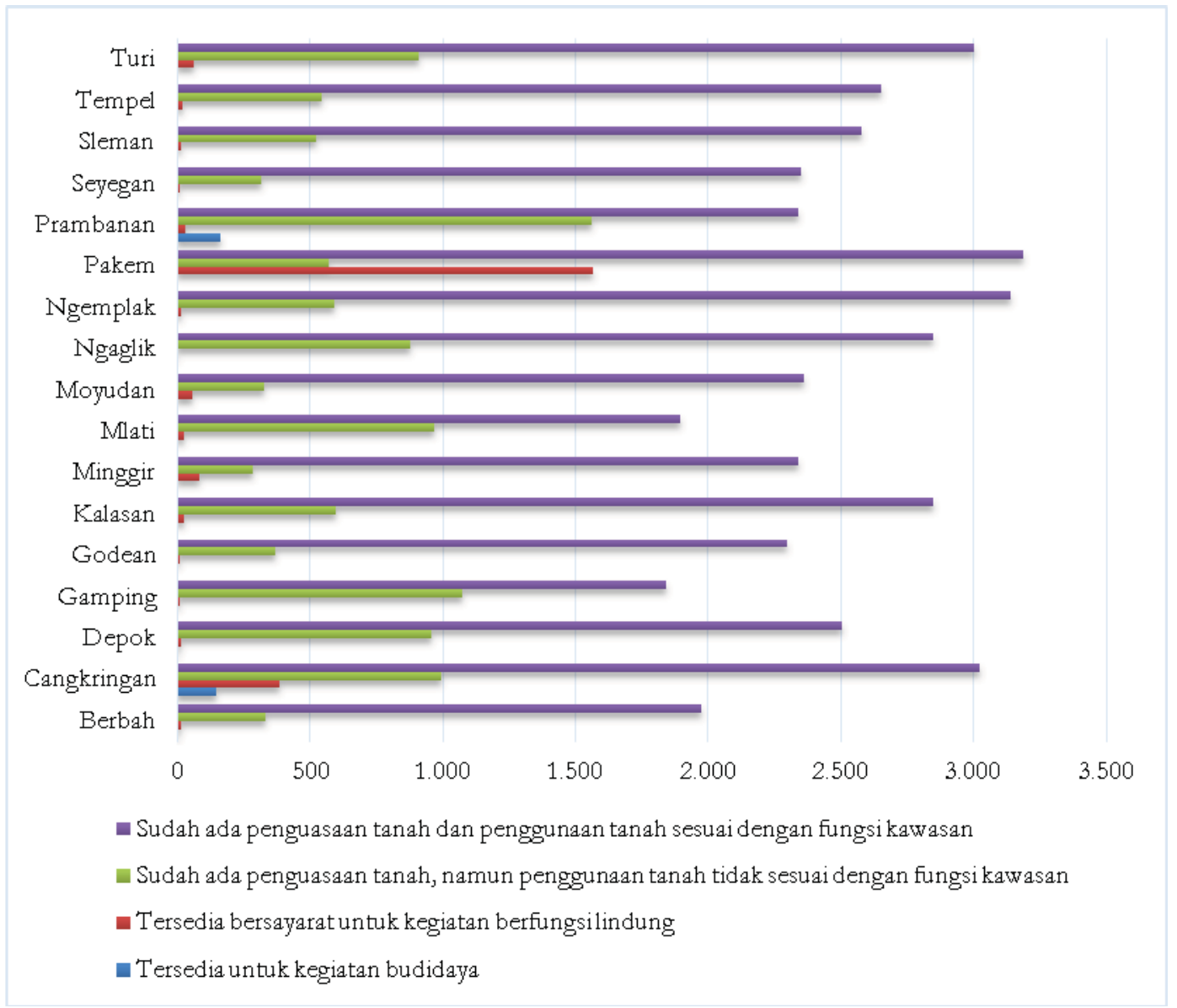

Sumber: Data Neraca Penatagunaan Tanah Tahun 2014

Kabupaten Sleman tersedia tanah untuk kegiatan budidaya yang sesuai tata ruang seluas 307,107 hektar atau 0,533 persen dari luas Kabupaten Sleman, tersedia bersyarat untuk kegiatan berfungsi lindung seluas 2.327,937 hektar atau 4,041 persen dari luas Kabupaten Sleman. Sedangkan untuk tanah yang telah ada penguasaan dan atau penggunaan tanah, tersedia dalam rangka penyesuaian penggunaan tanah (sudah ada penguasaan tanah, namun 
Samudra Ivan Supratikno, Armaidy Armawi, dan Djaka Marwasta -- Pemanfaatan Neraca Penatagunaan Tanah Dalam Mendukung Penyusunan Sistem Informasi Ketahanan Pangan Pokok Wilayah (Studi Di Kabupaten Sleman, Daerah Istimewa Yogyakarta)

penggunaan tanah tidak sesuai dengan RTRW) seluas 11.793,544 hektar atau 20,470 persen dari luas wilayah keseluruhan dan tersedia dalam rangka optimalisasi penggunaan tanah (sudah ada penguasaan tanah dan penggunaan tanah sesuai dengan RTRW) seluas 43.185,124 hektar atau 74,956 persen dari luas Kabupaten Sleman.

Dalam mendukung penyediaan lahan pertanian pangan berkelanjutan untuk ketahanan pangan berikut disajikan tabel 5 mengenai distribusi untuk penyediaan tanah untuk komoditas pangan pendukung ketahanan pangan Berdasarkan tabel 5, persediaan tanah paling besar adalah untuk kegiatan pertanian jika dilakukan penjumlahan ketersediaan tanahnya maka didapat bahwa luasan ketersediaan untuk tanaman padi sebesar 40,36 persen, untuk tanaman kelapa, nangka, mangga dan buah-buahan sebesar 10,97 persen, untuk komoditas tanaman kelapa, nangka, jagung ketela dan ubi sebesar 6,03 persen, untuk tanaman pinus, cemara, akasia dan tanaman keras sebesar 2,95 persen, dan untuk kebun sejenis salak sebesar 1,58 persen. Pengolahan data menunjukkan bahwa kegiatan untuk tanaman padi dan pemukiman/ perumahan hampir sama luasannya.

\section{Kondisi Produksi Komoditas Tanaman Pangan Pokok}

Permasalahan sektor pertanian di Yogyakarta, selama 5 tahun terakhir lahan pertanian berkurang sekitar 200 hektar. Banyak lahan yang beralih untuk pembangunan perumahan di wilayah Yogyakarta sehingga

Tabel 5

Persediaan Tanah untuk Kawasan Pertanian dengan Komoditas

\begin{tabular}{|c|c|c|c|c|c|c|c|c|c|c|c|}
\hline \multirow{3}{*}{ No. } & \multirow{3}{*}{ Jenis Komoditas } & \multicolumn{8}{|c|}{ Klasifikasi Ketersediaan Tanah } & \multirow{3}{*}{$\begin{array}{c}\text { Total } \\
\text { Ketersediaan } \\
\text { Berdasarkan } \\
\text { Luas (Ha) }\end{array}$} & \multirow{3}{*}{$\begin{array}{c}\text { Total } \\
\text { Ketersediaan } \\
\text { Berdasarkan } \\
\text { Wilayah (\%) }\end{array}$} \\
\hline & & \multicolumn{2}{|c|}{$\begin{array}{c}\text { Tersedia Untuk } \\
\text { Kegiatan Budidaya }\end{array}$} & \multicolumn{2}{|c|}{$\begin{array}{c}\text { Tersedia } \\
\text { Bersayarat } \\
\text { Untuk Kegiatan } \\
\text { Berfungsi } \\
\text { Lindung }\end{array}$} & \multicolumn{2}{|c|}{$\begin{array}{c}\text { Sudah Ada } \\
\text { Penguasaan Tanah, } \\
\text { Namun Penggunaan } \\
\text { Tanah Tidak Sesuai } \\
\text { Dengan Fungsi } \\
\text { Kawasan }\end{array}$} & \multicolumn{2}{|c|}{$\begin{array}{c}\text { Sudah Ada } \\
\text { Penguasaan Tanah } \\
\text { Dan Penggunaan } \\
\text { Tanah Sesuai } \\
\text { Dengan Fungsi } \\
\text { Kawasan }\end{array}$} & & \\
\hline & & Luas (Ha) & $\begin{array}{c}\text { Wilayah } \\
(\%)\end{array}$ & $\begin{array}{l}\text { Luas } \\
(\mathrm{Ha})\end{array}$ & $\begin{array}{c}\text { Wilayah } \\
(\%)\end{array}$ & Luas (Ha) & $\begin{array}{c}\text { Wilayah } \\
(\%)\end{array}$ & Luas (Ha) & $\begin{array}{c}\text { Wilayah } \\
(\%)\end{array}$ & & \\
\hline 1 & $\begin{array}{l}\text { Kebun Sejenis } \\
\text { Salak }\end{array}$ & 0,000 & 0,000 & 0,000 & 0,000 & 914,150 & 1,587 & 149,518 & 0,260 & $1.063,67$ & 1,85 \\
\hline 2 & $\begin{array}{l}\text { Kelapa, Nangka, } \\
\text { Jagung Ketela Dan } \\
\text { Ubi }\end{array}$ & 127,074 & 0,221 & 0,000 & 0,000 & $2.310,552$ & 4,010 & $1.039,001$ & 1,803 & $3.476,63$ & 6,03 \\
\hline 3 & $\begin{array}{l}\text { Kelapa, Nangka } \\
\text { Mangga Dan Buah- } \\
\text { Buahan }\end{array}$ & 245,356 & 0,426 & 0,451 & 0,001 & $3.737,240$ & 6,487 & $2.338,314$ & 4,059 & $6.321,36$ & 10,97 \\
\hline 4 & Padi & 14,121 & 0,025 & 0,000 & 0,000 & $18.766,920$ & 32,574 & $4.473,269$ & 7,764 & $23.254,31$ & 40,36 \\
\hline 5 & $\begin{array}{l}\text { Jagung, Ketela Dan } \\
\text { Ubi-Ubian }\end{array}$ & 3,470 & 0,006 & 0,000 & 0,000 & 324,366 & 0,563 & 126,811 & 0,220 & 454,65 & 0,79 \\
\hline 6 & $\begin{array}{l}\text { Perikanan Air } \\
\text { Tawar }\end{array}$ & 0,057 & 0,000 & 0,000 & 0,000 & 66,325 & 0,115 & 32,966 & 0,057 & 99,35 & 0,17 \\
\hline 7 & $\begin{array}{l}\text { Perikanan Air } \\
\text { Tawar Dengan } \\
\text { Penampung Air }\end{array}$ & 0,199 & 0,000 & 0,000 & 0,000 & 0,633 & 0,001 & 4,823 & 0,008 & 5,66 & 0,01 \\
\hline 8 & $\begin{array}{l}\text { Pinus, Cemara, } \\
\text { Akasia Dan } \\
\text { Tanaman Keras }\end{array}$ & $1.382,961$ & 2,400 & 166,184 & 0,288 & 132,353 & 0,230 & 22,345 & 0,039 & $1.703,84$ & 2,96 \\
\hline & Total & $1.773,24$ & 3,08 & 166,64 & 0,29 & $26.252,54$ & 45,57 & $8.187,05$ & 14,21 & $36.379,46$ & 63,14 \\
\hline
\end{tabular}

Sumber : Data Neraca Penatagunaan Tanah Tahun 2014 
pembangunan perumahanan ke depan harus secara vertikal. Peningkatan ketersediaan pangan tidak lepas dari berbagai inovasi dan kerjasama kebijakan antar pemerintah. Produk neraca penatagunaan tanah untuk sementara ini menjadi data pendukung dalam melakukan analisis ketersediaan tanah dalam rangka penyediaan lahan pertanian. Dengan melihat antara ketersediaan tanah dengan kondisi tata ruangnya diharapkan bahwa nantinya penataan ruang serta kepemilikan lahan pertanian sesuai dengan kondisi fisiografisnya dan memiliki landasan yuridis bagi pemilik tanahnya.

Pembangunan ketahanan pangan didasari oleh amanat Undang-Undang Nomor 41 Tahun 2009 tentang Perlindungan Lahan Pertanian Pangan Berkelanjutan dimana untuk menentukan dan menetapkan lahan pertanian yang dalam jangka waktu panjang tidak dapat dialihfungsikan. Amanat selain itu adalah Undang-Undang Nomor 18 Tahun 2012 tentang Pangan, yang mengamanatkan bahwa penyelenggaraan pangan dilakukan untuk memenuhi kebutuhan dasar manusia yang memberikan manfaat secara adil, merata, dan berkelanjutan berdasarkan kedaulatan pangan, kemandirian pangan, dan ketahanan pangan nasional.

Pemangku kebijakan sadar bahwa untuk mewujudkan kedaulatan, kemandirian dan ketahanan pangan merupakan hal mendasar yang sangat besar arti dan manfaatnya untuk mendukung pelaksanaan kebijakan terkait ketersediaan pangan bagi penduduknya. Pemerintah daerah dalam hal ini melalui pemerintah Propinsi mendukung kebijakan tersebut dengang mengeluarkan Peraturan Daerah Provinsi Daerah Istimewa Yogyakarta Nomor 10 Tahun 2011 tentang Perlindungan Lahan Pertanian Pangan Berkelanjutan. Dengan ditetapkannya Peraturan Daerah Nomor 10 Tahun 2011 tentang Perlindungan Lahan Pertanian Pangan Berkelanjutan, maka ada kewajiban bagi setiap kabupaten di Provinsi DIY untuk segera menyusun Raperda yang sama dengan substansi materi pengaturan sebaran di setiap kecamatan, desa, atau dusun.

Atas amanat tersebut pemerintah kabupaten merespon dengan mengeluarkan Peraturan Daerah Nomor 12 Tahun 2012 tentang Rencana Tata Ruang Wilayah Sleman dimana di dalamnya memuat strategi ketahanan pangan dan pengelolaan kawasan pertanian. Dalam Perda yang telah disebutkan di atas Kabupaten Sleman berharap dapat menyediakan luas paling kurang 12.377,59 hektar untuk penggunaan tanah pertanian. Pemerintah Kabupaten Sleman telah melaksanakan berbagai program atau kegiatan yang bermuara pada upaya pemantaban ketahanan pangan.

Program dan kegiatan urusan pertanian Kabupaten Sleman pada tahun 2011-2015 mampu mendukung produksi tanaman pangan berupa padi sawah dan ladang sebanyak 232.713 ton untuk pemenuhan kebutuhan beras di Kabupaten Sleman dan kabupaten lain di Daerah Istimewa Yogyakarta. Sementara produksi beberapa tanaman pangan lainnya mengalami penurunan karena terjadinya fenomena perubahan iklim yang ekstrim (curah hujan sangat tinggi) dan serangan organisme pengganggu tanaman yang semakin meningkat. Isu strategis pada urusan pertanian adalah masih cukup tingginya alih fungsi lahan, biaya produksi tidak sebanding dengan harga jual, belum optimalnya manajemen agribisnis, dan akses pemodalan yang belum merata. Isu strategis pada urusan ketahanan pangan adalah belum optimalnya diversifikasi produk pangan lokal untuk itu perlu optimalisasi sawah. 
Samudra Ivan Supratikno, Armaidy Armawi, dan Djaka Marwasta -- Pemanfaatan Neraca Penatagunaan Tanah Dalam Mendukung Penyusunan Sistem Informasi Ketahanan Pangan Pokok Wilayah (Studi Di Kabupaten Sleman, Daerah Istimewa Yogyakarta)

Berdasarkan hasil analisis neraca penatagunaan tanah kelompok penggunaan tanah yang paling luas adalah kelompok penggunaan tanah budidaya pertanian, yaitu sebesar 37.148,207 hektar pada tahun 2010 dan berkurang menjadi 33.419,418 hektar pada tahun 2014. Kelompok penggunaan tanah yang luasnya di bawah budidaya pertanian adalah kelompok penggunaan tanah budidaya non pertanian, yaitu sebesar 16.592,368 hektar pada tahun 2010 dan bertambah menjadi 19.494,926 hektar pada tahun 2014. Dengan demikian, penggunaan tanah budidaya memang lebih mendominasi di Kabupaten Sleman dan hanya sebagian kecil saja tanah yang merupakan non budidaya. Berkurangnya kelompok penggunaan tanah budidaya pertanian ini sebagian besar berubah menjadi penggunaan tanah budidaya non pertanian. Hal ini menunjukkan bahwa di Kabupaten Sleman juga banyak penggunaan tanah dari pertanian yang berubah menjadi non pertanian.

Gambar 3 menunjukkan produksi tanaman pangan dalam dua kurun waktu, yaitu pada tahun 2010 dan tahun 2014. Pada tahun 2010 konstribusi tanaman pangan dengan produksi terbesar adalah hortikultura dengan jenis tanaman buah dan sayuran memiliki komposisi hingga 76 persen, sementara itu padi sebagai bahan makanan pokok mencapai 19 persen dan palawija 5 persen. Pada tahun 2014 terjadi dinamika perubahan komposisi, walaupun secara makro masih sama komposisinya berdarkan peringkat, akan tetapi terjadi perubahan dalam jumlah produksi masing-masing komponen. Hortikultura naik menjadi 83 persen, padi 14 persen, dan palawija 3 persen. Gambaran secara makro tersebut memberikan informasi bahwa produksi tanaman hortikultura di Sleman secara makro mengalami peningkatan pada tahun 2014, sebagaimana gambar 4.

Dengan melihat distribusi penggunaan tanah dan tingkat produksi tanaman pangan hal ini mampu mendorong pengambilan kebijakan dalam menentukan kawasan untuk pertanian dalam tata ruang. Pada tahapan selanjutnya untuk mendukung kebijakan maka perlu dilakukan analisis kondisi ketahanan pangan di Kabupaten Sleman.

\section{Kondisi Ketahanan Pangan Pokok Wilayah Kabupaten Sleman}

Konsep ketahanan pangan oleh sebagian pakar dianggap sebagai konsep dengan kepentingan politik, pangan menjadi

Gambar 3

Produksi Tanaman Pangan di Kab. Sleman Tahun 2010 dan 2014 (Ton)
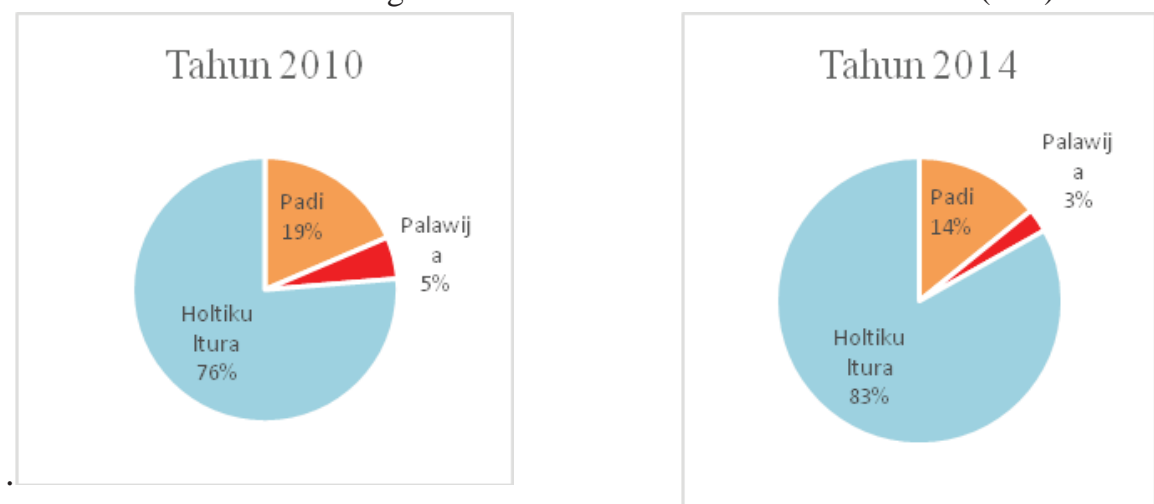

Sumber: Diolah dari BPS, Kecamatan Dalam Angka Kab Sleman Tahun 2010 dan 2014 
Gambar 4

Produksi Tanaman Pangan Pokok Sleman Tahun 2010 dan 2014

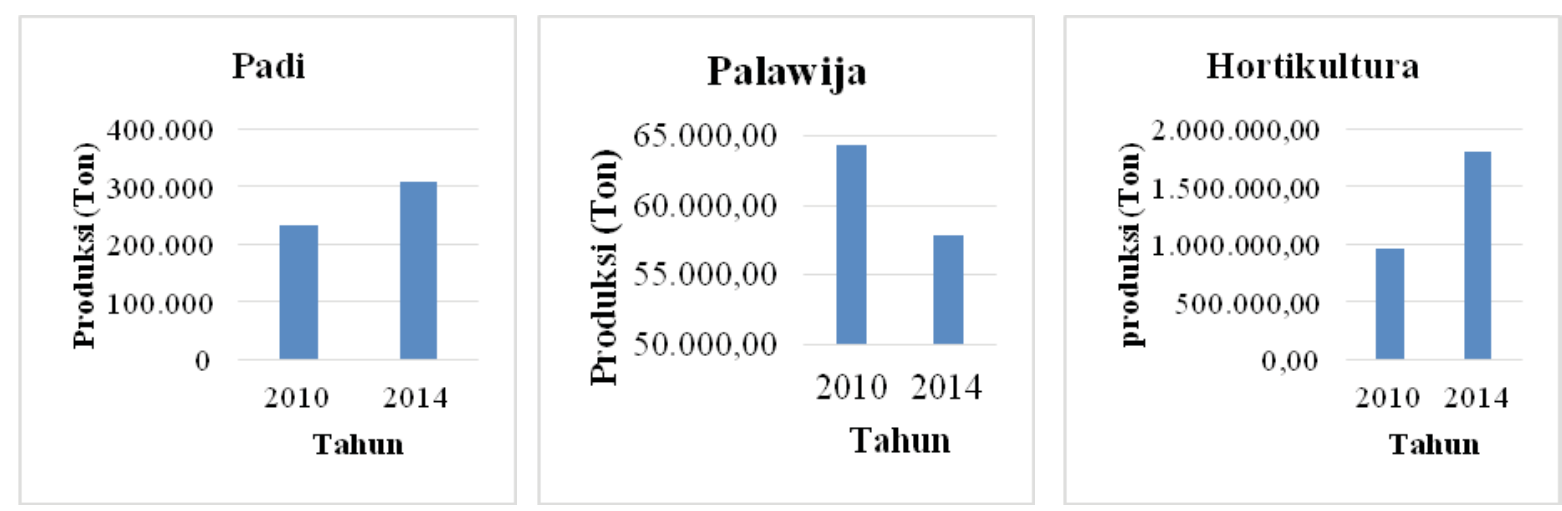

Sumber: BPS, Kecamatan Dalam Angka Kab Sleman Tahun 2010 dan 2014 (diolah)

komoditas yang dapat diperdagangkan secara lokal dan global sehingga pangan masuk ke dalam putaran perdagangan dunia (Yuwono, 2011:48). Ketahanan pangan terdiri dari tiga sub sistem utama yaitu ketersediaan, akses, dan penyerapan pangan, sedangkan status gizi merupakan outcome dari ketahanan pangan. Analisis mengenai kerentanan pangan perlu dilakukan hal ini untuk melihat kondisi aspek fisiografi terhadap kerentanan pangan penduduknya. Kerentanan pangan ini dengan menghitung penduduk yang rawan terhadap bencana, luas daerah berhutan dan daerah yang mengalami kerusakan produksi.

Berbagai upaya dalam urusan ketahanan pangan tidak hanya berfokus pada peningkatan ketersediaan pangan, pemerataan distribusi pangan dengan harga terjangkau dan tercapainya pola konsumsi pangan yang aman, bergizi dan beragam, namun juga meningkatkan peran masyarakat dan pihak swasta dalam mendukung ketahanan pangan. Program yang dilaksanakan telah mampu mempertahankan surplus pangan pokok, meskipun hasil produksi dan produktivitas mengalami penurunan dibandingkan dengan tahun sebelumnya. Dalam rangka analisis ketahanan pangan perlu penggabungan berbagai variabel. Analisis yang dibutuhkan yaitu ketersediaan pangan, distribusi pangan, konsumsi pangan dan kerentanan pangan. Neraca penatagunaan tanah dalam penelitian ini dijadikan data dasar dalam menentukan indeks kerentanan pangan. Indeks yang digunakan yaitu penentuan luas kawasan budidaya pertanian dan non budidaya pertanian.

Distribusi pangan merupakan salah satu subsistem ketahanan pangan yang peranannya sangat strategis, apabila tidak dapat terselenggara secara baik dan lancar, bahan pangan yang dibutuhkan masyarakat tidak akan terpenuhi. Distribusi pangan ini diharapkan dapat terlaksana secara efektif, efisien dan merata di setiap lokasi berlangsungnya transaksi bahan pangan kebutuhan masyarakat. Gangguan distribusi pangan ini berdampak terhadap kelangkaan bahan pangan dan kenaikan harga pangan serta berpengaruh terhadap rendahnya akses pangan masyarakat karena daya beli bahan pangan menjadi menurun. Berdasarkan analisis di atas menunjukkan bahwa akses terhadap pangan di hampir seluruh Kabupaten Sleman tidak mengalami kesulitan akses dan kemampuan pendapatan penduduknya cukup baik. 
Samudra Ivan Supratikno, Armaidy Armawi, dan Djaka Marwasta -- Pemanfaatan Neraca Penatagunaan Tanah Dalam Mendukung Penyusunan Sistem Informasi Ketahanan Pangan Pokok Wilayah (Studi Di Kabupaten Sleman, Daerah Istimewa Yogyakarta)

Pengolahan data untuk konsumsi pangan di Kabupaten Sleman menghasilkan indeks komposit dengan tingkat kerawanan pangan berada Kecamatan Depok dengan indeks 0,71 mengingat jumlah penduduknya juga cukup banyak di kecamatan ini. Selain itu Kecamatan Depok merupakan kecamatan yang berbatasan langsung dengan Kota Yogyakarta dimana daerah yang berbatasan langsung dengan kota merupakan kawasan aglomerasi Kota Yogyakarta. Kecamatan Cangkringan menjadi kecamatan yang memiliki potensi tahan pangan dengan indeks 0,30 dimana hal ini menunjukkan bahwa ketersediaan pangan berdasarkan konsumsi pangan dan jumlah populasi penduduknya masih dalam tingkatan yang baik dan tahan pangan. Dalam indeks yang sama untuk kecamatan lainnya memiliki potensi tahan pangan. Tahan pangan dengan kategori berpotensi terdapat di 9 kecamatan di Sleman dengan nilai indeks tahan pangan berada di Kecamatan Ngaglik dengan nilai 0,25 dan pada tingkatan cukup tahan pangan berada di Kecamatan Moyudan dan Ngemplak dengan nilai 0,36, sebagaimana tabel 6 .

Indeks ketersediaan pangan dengan nilai yang cukup jauh dibandingkan dengan kecamatan lainnya adalah Kecamatan Depok yaitu 0,71. Hasil perhitungan ke semua variabel menghasilkan output bahwa dari 17 kecamatan yang berada di Kabupaten Sleman hanya ada 2 daerah yang masuk ke dalam tingkat rawan pangan yaitu Kecamatan Depok dan Sleman. Analisis SIG memberikan gambaran yang baik dalam hal spasial pemetaan (mapping), sehingga distribusi Indeks Komposit Kerawanan Pangan di Kabupaten Sleman dapat terlihat polanya secara spasial, sebagaimana gambar 5 .

Tabel 6

Indeks Komposit Kerawanan Pangan Kab. Sleman

\begin{tabular}{clcccccc}
\hline No. & Kecamatan & $\begin{array}{c}\text { Indeks } \\
\text { Ketersediaan } \\
\text { Pangan }\end{array}$ & $\begin{array}{c}\text { Indeks } \\
\text { Pangan dan } \\
\text { Pendapatan }\end{array}$ & $\begin{array}{c}\text { Indeks } \\
\text { pemanfaatan/ } \\
\text { penyerapan } \\
\text { pangan }\end{array}$ & $\begin{array}{c}\text { Indeks } \\
\text { Kerentanan } \\
\text { Pangan }\end{array}$ & $\begin{array}{c}\text { Indeks } \\
\text { Komposit }\end{array}$ & Kondisi Relatif \\
\hline 1 & Moyudan & 0,35 & 0,40 & 0,36 & 0,24 & 0,40 & Cukup Berpotensi Tahan Pangan \\
2 & Minggir & 0,35 & 0,48 & 0,33 & 0,24 & 0,41 & Cukup Berpotensi Tahan Pangan \\
3 & Seyegan & 0,40 & 0,46 & 0,32 & 0,25 & 0,42 & Cukup Berpotensi Tahan Pangan \\
4 & Godean & 0,47 & 0,43 & 0,29 & 0,23 & 0,41 & Cukup Berpotensi Tahan Pangan \\
5 & Gamping & 0,55 & 0,34 & 0,31 & 0,30 & 0,45 & Cukup Berpotensi Tahan Pangan \\
6 & Mlati & 0,57 & 0,34 & 0,28 & 0,29 & 0,44 & Cukup Berpotensi Tahan Pangan \\
7 & Depok & 0,71 & 0,23 & 0,30 & 0,52 & 0,51 & Cukup Berpotensi Rawan Pangan \\
8 & Berbah & 0,45 & 0,42 & 0,31 & 0,20 & 0,40 & Cukup Berpotensi Tahan Pangan \\
9 & Prambanan & 0,35 & 0,55 & 0,30 & 0,32 & 0,46 & Cukup Berpotensi Tahan Pangan \\
10 & Kalasan & 0,44 & 0,46 & 0,32 & 0,30 & 0,46 & Cukup Berpotensi Tahan Pangan \\
11 & Ngemplak & 0,40 & 0,40 & 0,36 & 0,30 & 0,44 & Cukup Berpotensi Tahan Pangan \\
12 & Ngaglik & 0,49 & 0,40 & 0,25 & 0,28 & 0,45 & Cukup Berpotensi Tahan Pangan \\
13 & Sleman & 0,43 & 0,50 & 0,32 & 0,38 & 0,47 & Cukup Berpotensi Rawan Pangan \\
14 & Tempel & 0,39 & 0,48 & 0,33 & 0,26 & 0,43 & Cukup Berpotensi Tahan Pangan \\
15 & Turi & 0,32 & 0,45 & 0,31 & 0,32 & 0,43 & Cukup Berpotensi Tahan Pangan \\
16 & Pakem & 0,32 & 0,44 & 0,29 & 0,61 & 0,42 & Cukup Berpotensi Tahan Pangan \\
17 & Cangkringan & 0,30 & 0,48 & 0,33 & 0,39 & 0,40 & Cukup Berpotensi Tahan Pangan \\
\hline
\end{tabular}

Sumber: Hasil Analisis 
Gambar 5

Peta Ketahanan Pangan Kabupaten Sleman 2014

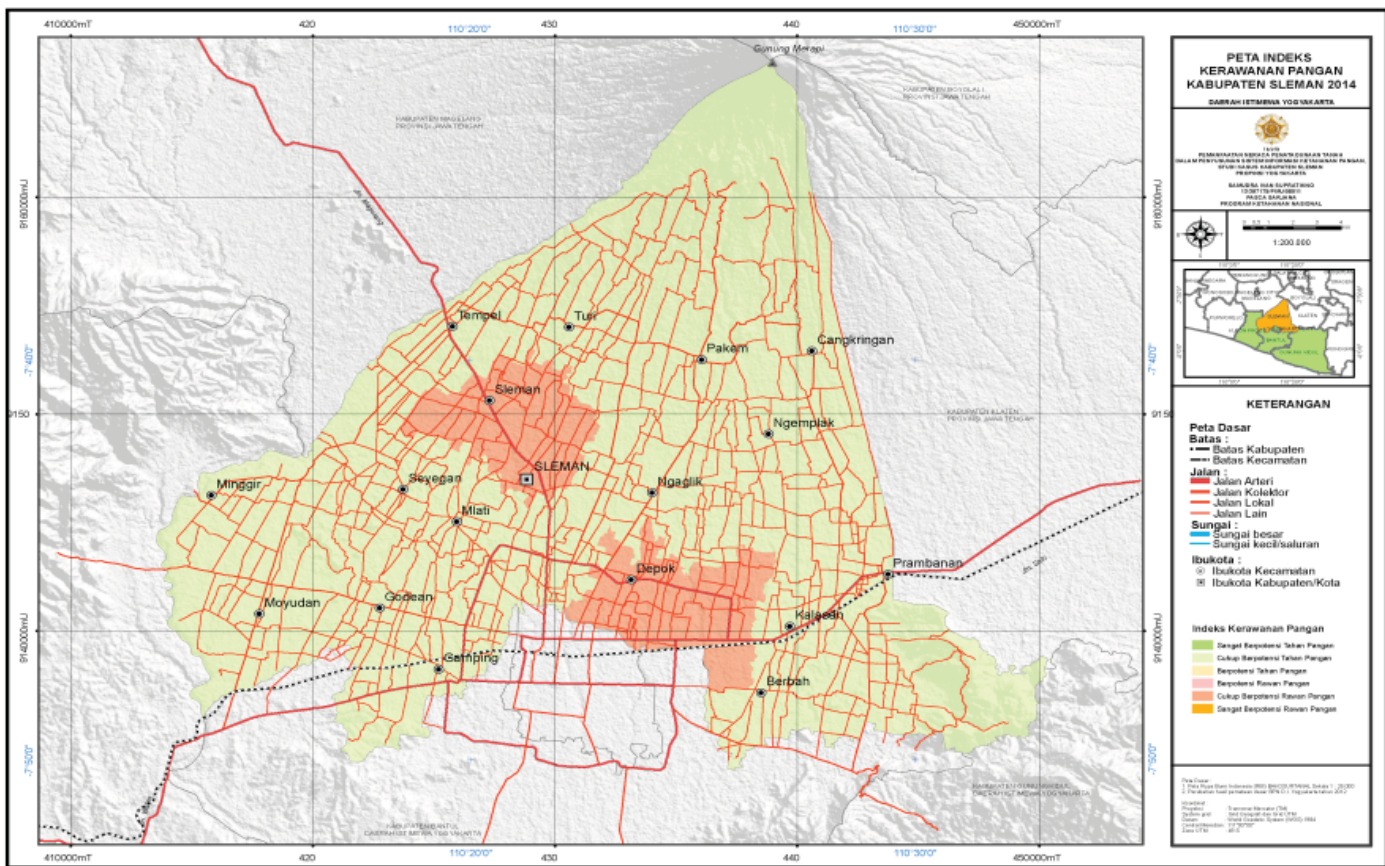

Sumber: Bappeda Kabupaten Sleman 2014

Tabel 7

Ringkasan Hasil Uji Validitas

\begin{tabular}{|c|c|c|c|c|c|}
\hline $\begin{array}{l}\text { Potensi Rawan } \\
\text { Pangan }\end{array}$ & Indikator & $\begin{array}{l}\text { Nilai Korelasi } \\
\quad\left(\mathbf{r}_{\text {hitung }}\right)\end{array}$ & $\begin{array}{c}\mathbf{r}_{\text {tabel }} \\
(\alpha=5 \%)\end{array}$ & Pengujian & Keterangan \\
\hline \multirow[t]{2}{*}{ Ketersediaan Pangan } & Ketersediaan Tanaman Pangan Serealia & 0,988 & \multirow[t]{2}{*}{0,351} & \multirow{2}{*}{$r_{\text {hitung }}>r_{\text {tabel }}$} & \multirow[t]{2}{*}{ Valid } \\
\hline & Panjang Jalan & 0,771 & & & \\
\hline \multirow[t]{2}{*}{ Distribusi Pangan } & Keterjangkauan akses & 0,815 & \multirow[t]{3}{*}{0,351} & \multirow{3}{*}{$r_{\text {hitung }}>r_{\text {tabel }}$} & \multirow[t]{2}{*}{ Valid } \\
\hline & Infrastruktur Pendukung & 0,823 & & & \\
\hline \multirow{5}{*}{ Konsumsi Pangan } & Infrastruktur Kesehatan & 0,695 & & & \multirow{5}{*}{ Valid } \\
\hline & Anak Berat Badan Kurang & 0,797 & \multirow{4}{*}{0,351} & \multirow{4}{*}{$r_{\text {hitung }}>r_{\text {tabel }}$} & \\
\hline & Angka Kematian Bayi & 0,664 & & & \\
\hline & Perempuan Buta Huruf & 0,611 & & & \\
\hline & Penduduk Rawan Bencana & 0,781 & & & \\
\hline \multirow[t]{2}{*}{ Kerentanan Pangan } & Kawsan Budidaya Pertanian & 0,642 & \multirow[t]{2}{*}{0,351} & \multirow[t]{2}{*}{$r_{\text {hitung }}>r_{\text {tabel }}$} & \multirow[t]{2}{*}{ Valid } \\
\hline & Bukan Kawasan Budidaya Pertanian & 0,449 & & & \\
\hline
\end{tabular}

Sumber : Hasil Analisis Statistik

\section{Analisis Statistik Kondisi Ketahanan Pangan Pokok Wilayah}

Adapun uji validitas dalam aspek kerawanan pangan dapat dijabarkan dalam tabel 7.

Berdasarkan pengujian dengan statistik, menunjukkan bahwa indikator potensi rawan pangan pada masing-masing kelompok aspek kerawanan pangan memiliki signifikansi dengan taraf 5 persen $(0,05)$ yang memiliki arti bahwa terdapat korelasi yang signifikan serta valid pada indikator kerawanan pangan dalam analisis ketahanan pangan dalam penelitian ini. 
Samudra Ivan Supratikno, Armaidy Armawi, dan Djaka Marwasta -- Pemanfaatan Neraca Penatagunaan Tanah Dalam Mendukung Penyusunan Sistem Informasi Ketahanan Pangan Pokok Wilayah (Studi Di Kabupaten Sleman, Daerah Istimewa Yogyakarta)

Pada pengujian tingkat reabilitas hasil yang didapatkan berdasarkan pada tabel 8 dinyatakan reliabel. Penggunan metode Alpha Cronbach digunakan untuk memudahkan dalam menghasilkan analisis pada aspek kerawanan pangan sebagai indikator ketahanan pangan wilayah.

Tabel 8

Ringkasan Hasil Uji Reliabilitas

\begin{tabular}{lcc}
\hline \multicolumn{1}{c}{$\begin{array}{c}\text { Potensi Rawan } \\
\text { Pangan }\end{array}$} & $\begin{array}{c}\text { Koefisien Alpha } \\
(\boldsymbol{\alpha})\end{array}$ & Keterangan \\
\hline Ketersediaan Pangan & 0,984 & Reliabel \\
Distribusi Pangan & 0,841 & Reliabel \\
Konsumsi Pangan & 0,769 & Reliabel \\
Kerentanan Pangan & 0,915 & Reliabel \\
\hline
\end{tabular}

Sumber : Hasil Analisis Statistik

Selanjutnya, analisis regresi linier dapat ditunjukkan dalam tabel 9.

Tabel 9 merupakan hasil ringkasan pengujian regresi variabel indikator kerawanan pangan untuk menentukan kualitas masingmasing hubungan indikator di wilayah kecamatan. Penggunaannya dengan regresi linear berganda dengan tujuan menghasilkan besaran kekuatan antar indikator kerawanan pangan. Dihasilkan nilai dengan nilai uji probabilitas yang signifikan dan memiliki korelasi hubungan pada masing-masing indikator terhadap dampak ketahanan pangan dengan rincian sebagai berikut.

Pertama, ketersediaan pangan memiliki derajat uji yang berpengaruh signifikan terhadap potensi kerawanan pangan yang dapat menyebabkan kerawanan terhadap ketahanan pangan dimana nilai $\mathrm{t}=2,770$, yang berarti lebih besar dari hasil nilai tabel regresi yaitu $\mathrm{t}=$ 2,042 dengan probabilitas 0,010 lebih kecil dari koefisien 0,05. Nilai yang dihasilkan dari rumus perhitungan regresi adalah 0,311 dimana hasil ini menunjukkan bahwa ketersediaan pangan berpengaruh terhadap kerawanan pangan

Kedua, distribusi pangan memiliki derajat uji yang berpengaruh signifikan terhadap potensi kerawanan pangan yang dapat menyebabkan dampak pada kondisi ketahanan pangan dimana nilai $\mathrm{t}=3,8848$, yang berarti lebih besar dari hasil nilai tabel regresi yaitu $\mathrm{t}=$ 2,042 dengan probabilitas 0,001 lebih kecil dari koefisien 0,05. Nilai yang dihasilkan dari rumus perhitungan regresi adalah 0,3848 dimana hasil ini menunjukkan bahwa infrastruktur dan jalan berpengaruh terhadap ketahanan pangan.

Ketiga, konsumsi pangan memiliki derajat uji yang berpengaruh signifikan terhadap potensi kerawanan pangan yang dapat menyebabkan dampak pada kondisi ketahanan pangan dimana nilai $\mathrm{t}=2,319$, yang berarti lebih besar dari hasil nilai tabel regresi yaitu $t=2,042$ dengan probabilitas 0,030 lebih kecil dari koefisien 0,05. Nilai yang dihasilkan dari rumus perhitungan regresi adalah 0,3742 dimana hasil ini menunjukkan bahwa ketersediaan tanah berpengaruh terhadap ketahanan pangan.

Tabel 9

Ringkasan Hasil Uji Regresi Linear

\begin{tabular}{lrcrr}
\hline $\begin{array}{c}\text { Indikator } \\
\text { Kerawanan Pangan }\end{array}$ & $\begin{array}{r}\text { Koefisien } \\
\text { Alpha }(\boldsymbol{\alpha})\end{array}$ & t & Probabilitas & Keterangan \\
\hline Ketersediaan Pangan & 0,311 & 2,770 & 0,010 & Signifikan \\
Distribusi Pangan & 0,332 & 3,848 & 0,001 & Signifikan \\
Konsumsi Pangan & 0,247 & 2,319 & 0,030 & Signifikan \\
Kerentanan Pangan & 0,259 & 3,742 & 0,010 & Signifikan \\
\hline
\end{tabular}

Sumber : Hasil Analisis Statistik 
Keempat, kerentanan pangan memiliki derajat uji yang berpengaruh signifikan terhadap potensi kerawanan pangan yang dapat menyebabkan dampak pada kondisi ketahanan pangan dimana nilai $\mathrm{t}=3,742$, yang berarti lebih besar dari hasil nilai tabel regresi yaitu $\mathrm{t}=$ 2,042 dengan probabilitas 0,030 lebih kecil dari koefisien 0,05 . Nilai yang dihasilkan dari rumus perhitungan regresi adalah 0,259 dimana hasil ini menunjukkan bahwa kesesuaian penggunaan tanah berpengaruh terhadap ketahanan pangan.

\section{SIMPULAN}

Berdasar uraian di atas dapat ditarik simpulan sebagai berikut.

Pertama, kondisi sebaran penatagunaan tanah di Kabupaten Sleman didominasi oleh lahan terbangun. Hasil pengolahan data menunjukkan bahwa kondisi Sleman sebelum tahun 2014 memiliki sebaran penggunaan tanah pertanian yang luas di berbagai kecamatan. Seiring dengan meningkatnya jumlah penduduk dan pengaruh aglomerasi Kota Yogyakarta penggunaan tanah untuk pertanian di Kabupaten Sleman dialihfungsikan menjadi permukiman/ kampung dan perumahan. Kecamatan dengan tingkat konversi penggunaan tanah pertanian paling besar adalah Kecamatan Depok dimana luasan 1.876,11 hektar atau sekitar 52,77 persen dari luas wilayah kecamatan tersebut.

Kedua, kondisi neraca penatagunaan tanah di Kabupaten Sleman memiliki tingkat kesesuaian antara penggunaan tanah dengan peruntukan kawasan dalam RTRW adalah 79,001 persen (45.515,247 hektar) dari seluruh luas wilayah Kabupaten Sleman, sedangkan sebesar 20,999 persen (12.098,465 hektar) merupakan penggunaan tanah yang tidak sesuai dengan peruntukan kawasan dalam RTRW. Terdapat perubahan penggunaan tanah yang dominan di Kabupaten Sleman, dari tahun 2008 - 2014, yaitu sawah irigasi berkurang sebesar 4,701 persen (2.708,586 hektar), tegalan berkurang 2,736 persen (1.576,598 hektar), sementara penggunaan tanah pemukiman/kampung bertambah sebesar 3,935 persen (2.266,815 hektar) dari luas Kabupaten Sleman. Kondisi penggunaan tanah seluas 57.613,712 hektar di Kabupaten Sleman terdapat ketidaksesuaian penggunaan tanah terhadap arahan fungsi kawasan dalam RTRW sebesar 20,99 persen (12.098,465 hektar). Ketidaksesuaian yang paling dominan adalah pada kawasan pemukiman sebesar 12,437 persen (7.165,578 hektar). Dengan hasil analisis neraca penatagunaan tersebut harapannya dapat memberikan masukan dalam menindaklanjuti penentuan kebijakan dan strategi kawasan pertanian untuk ketahanan pangan.

Ketiga, perhitungan neraca penatagunaan tanah sebagai data pendukung dalam melakukan analisis ketahanan pangan. Data neraca yang digunakan dalam analisis tersebut adalah data kawasan budidaya pertanian dan non-pertanian untuk menentukan nilai indeks luas lahan pertanian dalam penentuan kerentanan pangan. Dalam mendukung analisis ketahanan pangan selain data neraca digunakan data mengenai ketersediaan pangan, distribusi pangan dan konsumi pangan untuk menggambarkan kondisi ketahanan pangan di Kabupaten Sleman. Berdasarkan analisis dengan menggunakan beberapa indikator tersebut didapatkan bahwa kondisi 15 kecamatan di Kabupaten Sleman masuk kedalam kategori tahan pangan dan 2 kecamatan yaitu Kecamatan 
Samudra Ivan Supratikno, Armaidy Armawi, dan Djaka Marwasta -- Pemanfaatan Neraca Penatagunaan Tanah Dalam Mendukung Penyusunan Sistem Informasi Ketahanan Pangan Pokok Wilayah (Studi Di Kabupaten Sleman, Daerah Istimewa Yogyakarta)

Depok dan Sleman masuk ke dalam kategori daerah berpotensi rawan pangan. Kecamatan yang berpotensi rawan pangan ini memiliki karakteristik kota, dimana Kecamatan Sleman merupakan ibukota dari Kabupaten Sleman dan Kecamatan Depok yang berbatasan langsung dengan Kota Yogyakarta dan mengalami dampak dari perkembangan kota tersebut. Hasil uji statistik menunjukkan bahwa variabel yang mempengaruhi kerawanan pangan memiliki koefisien alpha yang reliabel yaitu dengan nilai 0,984 pada indeks ketersediaan pangan 0,8411 pada indeks distribusi pangan, 0,769 pada konsumsi pangan dan 0,915 pada kerentanan pangan.

\section{DAFTAR PUSTAKA}

Habbakuk, HJ, 1970, Historical Experience of Economic Development, California: Wadworth Publising Co.

Iqbal, Muhammad dan Sumaryanto, 2007, “ Strategi Pengendalian Alih Fungsi Lahan Pertanian Bertumpu pada Partisipasi Masyarakat”. Analisis Kebijakan Pertanian Volume 5/2010:”. Jakarta: Kementan

Jayadinata, Johara T., 1999. Tata Guna Tanah Dalam Perencanaan Pedesaan Perkotaan dan Wilayah. Bandung: Penerbit ITB

Rosset, Peter. 2003. "Global Rallying Cry of Farmer Movement, Backgrounder”.
Journal of Food Sovereignty, Vol. 9 Num. 4, France: Nyèlèni

Santoso, Urip, 2005. Hukum Agraria \& HakHak Atas Tanah. Jakarta: Prenada

Steigenga, W, 1964. Modern Planologie. Utrecht: Aula Boeken Het Spectrum

Webb, Pattrick. 2003. Cultivated Capital: Agriculture, Food Systems and Sustainable Development. Boston: TUFTS University

Yuwono, Triwibowo, 2011, Pembangunan Pertanian: Membangun Kedaulatan Pangan, Yogyakarta: Gadjah Mada Press

\section{Peraturan Perundangan}

Undang-Undang Republik Indonesia. Nomor 41 Tahun 2009. Tentang

Perlindungan Lahan Pertanian Pangan Berkelanjutan

Undang-Undang Republik Indonesia. Nomor 18 Tahun 2012 Tentang Pangan

Peraturan Pemerintah Republik Indonesia

Nomor 16 Tahun 2004 Tentang Penatagunaan Tanah

Peraturan Daerah Provinsi Daerah Istimewa Yogyakarta Nomor 10 Tahun 2011

Tentang Perlindungan Lahan Pertanian Pangan Berkelanjutan.

Peraturan Daerah Nomor 12 Tahun 2012 Tentang Rencana Tata Ruang Wilayah Sleman 